\title{
AUTUMN DREAMS: SERVIUS ON AEN. 6, 282-284
}

\section{Maria N. Kazanskaya}

Institute for Linguistic Studies of the Russian Academy of Sciences; 9, Tuchkov per.,

St. Petersburg, 199004, Russian Federation; subura@mail.ru

St. Petersburg State University, 7-9, Universitetskaya nab.,

St. Petersburg, 199034, Russian Federation; m.kazanskaya@spbu.ru

The paper examines an ancient superstition evoked in Servius' commentary (Serv. ad Aen. 6, 284); Servius mentions that, according to a certain authority on dreams, visions seen in the autumn months are particularly untrustworthy. The first part of the article reviews other references to this popular belief (Plut. Quaest. conv. 8, 10, 734d-736b; Alciphr. Ep. 2, 2; Basil. Ep. 207, 1). The second part attempts to reconstruct the reasoning of the authority that Servius had used (qui de somniis scripserunt) and at the same time to distinguish Servius' own view on the matter. It is shown that, although the remark on the unreliability of autumn dreams in itself is of little pertinence to the understanding of Virgil's text, it is part of a larger, fairly elaborate exegetical tradition that sought to establish a connection between Aen. 6, 282-284 and 6, 893-898.

Keywords: Virgil, Servius, gates of dreams, ancient superstitions, Plutarch, Alciphron, St. Basil, Aristotle on dreams, Democritus on dreams.

Aeneas' descent into the Underworld in the Aeneid 6 begins with the vestibulum Orci. The description of this sombre place (Aen. 6, 273-294), swarming with allegorical figures and mythical monsters, is centred on the great Elm standing in the middle of the vestibulum:

In medio ramos annosaque bracchia pandit

Ulmus opaca, ingens, quam sedem Somnia vulgo

vana tenere ferunt, foliisque sub omnibus haerent (Aen. 6, 282-284).

"In the middle an Elm, shadowy and enormous, spreads its branches - the space occupied, as men say, by uncertain Dreams, and they cling under every leaf".

With these three verses Vergil provides a pause in his catalogue of monsters, neatly dividing them into two groups, but also introduces what is evidently a piece of ancient folklore. ${ }^{1}$ Servius' commentary on these lines is mainly concerned with Vergil's choice of words and stylistic effects: the grammarian speculates on the exact reference of the expression in medio, notes the juxtaposition of the epithets opaca and ingens, explains the meaning of the adverb vulgo. Special attention is given to the epithet vana that qualifies the Dreams nesting on the Elm:

FOLIISQVE SVB OMNIBVS HAERENT. Qui de somniis scripserunt dicunt, quo tempore folia de arboribus cadunt, vana esse somnia: quod per transitum tetigit. Vana autem ideo, quia ab inferis; nam



${ }^{1}$ Cf. Vergil's use of ferunt (v. 284) which has long been recognized as his standard means of referring to some antiquarian tradition (cf. Austin 1977, 121: "it is a traditional legend $\langle\ldots$.. or at least Virgil wishes it to appear as such"). On traces of folklore in Vergil's description of the Elm, see also Norden 1903, 211; Tabárez 2010, 33-36.

(c) St. Petersburg State University, 2017 
"Those who wrote on dreams say that dreams are uncertain in the season when leaves fall from the trees; Vergil alluded to this belief in passing. But dreams are uncertain because they are sent by the gods of the Underworld; for real dreams are sent from above. Homer: 'For the dream, too, comes from Zeus"'

Servius shuns the most evident solution, namely, that vana is a generic epithet highlighting the fickleness of dreams. ${ }^{2}$ Instead, the grammarian unexpectedly indicates a possible allusion to the belief that dreams seen in late autumn are unreliable, and then goes on to suggest that dreams sent from Hades are unreliable, while those that come from

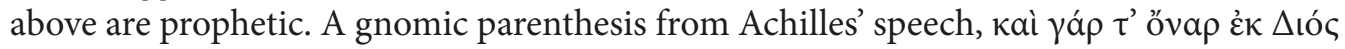
દ̇otív (Il. 1, 63) is added in corroboration of this idea: the quotation must have been taken from a second-hand source and does not evoke the original context of the utterance. This scholium is common to the Servius' original commentary and to the so-called Servius auctus; ${ }^{3}$ the latter adds, however, an alternative explanation for Vergil's placing of vana somnia on the Elm, visibly linking unreliable dreams with drinking (unfortunately, the end of the remark in lost):

Et quidam tradunt ideo in ulmo somnia inducta, quod vino gravati vana somnient et ulmus apta sit viti; et ideo apud inferos rem inanem. $\dagger$ (Serv. Dan. ad Aen. 6, 283).

"And some also say that dreams nestle in the Elm, because those who are overpowered with wine see uncertain dreams, and because the Elm is well adapted for the grape vines; and because in the underworld uncertain things."

While the information given by Servius is certainly of interest, the remark on the unreliability of dreams seems largely out of place. Vergil is speaking of a tree in the underworld that cannot be subject to changes of season, while the superstition refers to late autumn months; moreover, Servius mentions the moment when trees lose their foliage, suggesting a parallelism between dreams that disappear without trace and the autumn leaves, while Vergil, on the other hand, had specifically used the verb haerere of the flock of dreams holding firmly on to the branches of the Elm. ${ }^{4}$ It comes as no surprise therefore that the grammarian's remark is not taken seriously by modern commentators

2 This possibility is briefly mentioned in form of a question in the Servius auctus (a version of Servius' commentary with numerous supplements first published in the year 1600 by Pierre Daniel): VANA TENERE

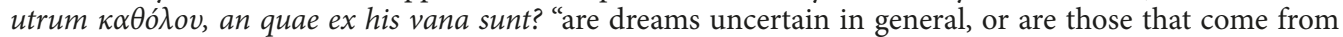
[infernal deities] uncertain?" (Serv. Dan. ad Aen. 6, 284). The supplements of the Servius auctus are heterogenous, encompassing material that ranges from Donatus to other scholars of the late Antiquity (Macrobius, Isidore of Seville) to medieval sources. For the current passage, the exact source of the additamentum is impossible to determine.

3 The unreliability of autumn dreams was also mentioned in the Mythographus Vaticanus III (a mythological compendium compiled by the late XII century scholar Master Alberic of London) in the section on the gates of sleep: Somnia vana sub foliis refert haerere Vergilius, quia qui de somniis tractarunt, quo tempore folia de arboribus cadunt, vana esse somnia dixerunt "Vergil recounts that uncertain dreams cling under leaves, because those who wrote on dreams said that dreams are uncertain in the season when the leaves fall from trees" (Myth. Vat. III, 24, 6). The resemblance of wording, as well as an earlier evocation of Servius, leaves little doubt that Alberic took the information directly from Servius (cf. Dain 2005, 120 n. 129).

4 The impression of the dreams' active tenacity is conferred by the verbs tenere and haerent, as has been noted by Tabárez 2010, 30. I thank Prof. Gavrilov for calling my attention to the contradiction between Servius' remark and Vergil's use of the verb haerent. 
of Vergil. ${ }^{5}$ E. Jeunet-Mancy in her commentary on Servius only points out that the connection between leaves and dreams seems unparalleled (contrary to the explanation in the Servius auctus of untrustworthiness of autumn dreams through the properties of wine in the fall that finds parallels in other writers ${ }^{6}$ ), and that Servius' source in this case is difficult to establish. ${ }^{7}$

Although the relevance of Servius' remark for Vergil's text is not immediately obvious, one is reluctant to write it off as a gratuitous piece of information that found its way into the commentary due to a loose association. In compiling his commentary, Servius never lost sight of his main goal, which was to provide the students with a guide to Vergil's text: the majority of his remarks are concerned with language and style, and other types of exegesis are present only when they were deemed strictly necessary; ${ }^{8}$ similarly, the grammarian consistently seeks to eliminate apparent textual problems, not to suggest novel, textually unmotivated interpretations of the text. ${ }^{9}$ It thus seems worthwhile to examine this seeming exception to Servius' usual practice. We will start by tracing other texts that mention the superstition, while the second part of the article will aim at reconstructing the reasoning behind Servius' reference to it in his scholium on Aen. 6, 284.

\section{The superstition}

Although the belief that late autumn dreams cannot be trusted is regularly overlooked in modern treatments of ancient superstitions, ${ }^{10}$ it is attested in several texts from the late antiquity. One of the fictitious Rustic Letters of Alciphron in which the farmer Iophon tells his friend Eraston of the dream he had seen the previous night gives us an important insight into the type of contexts in which this belief could be evoked:

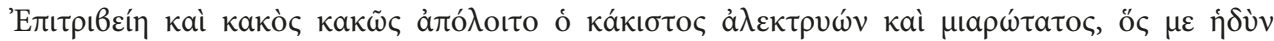

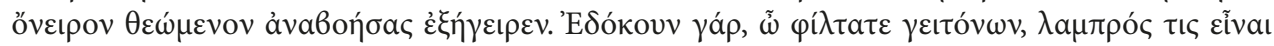

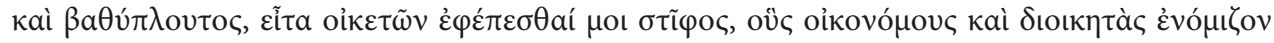





${ }^{5}$ Heyne 1832, 893-894 and Norden 1903, 210-212 mention Servius only with regard to the meaning of the adverb vulgo. Conington 1863, 284 briefly summarises Servius' idea passing no judgement on its relevance. Austin 1977, 121 only remarks on Servius' association of the somnia vana in the vestibulum Orci and with the falsa insomnia and the ivory gates through which Aeneas leaves the Hades described by Vergil at the end of Aeneas' journey in the Hades (Aen. 6, 896-898).

${ }^{6}$ Cf., in particular, Plat. Resp. 9, 571c-572a; Cic. De div. 1, 29, 60 ; Plin. Nat. Hist. 10, 211; Macr. Somn. Scip. 1, 3, 4, as well as Basil. Ep. 210, 2-3 which will be mentioned below.

7 Jeunet-Mancy 2012, 228 n. 360: «Servius ne précise pas quels sont les auteurs auxquels il se réfère ici. 'Ceux qui ont écrit sur les songes' sont nombreux, d'Homère à Artémidore d'Éphèse, en passant par Aristote et Cicéron. On trouve bien chez Pline l'Ancien (Histoire naturelle XXVIII, 14) une allusion à une propension aux rêves qui serait plus grande au printemps et en automne, mais rien qui corresponde vraiment à ce que dit le grammairien. »

${ }^{8}$ For a full description of Servius' methods and aims, see Kaster 1997, 169-197 (see esp. 170); cf. also Stocker's distinction between Servius' commentary and the Servius auctus: "The vulgate Servius is a Vergil commentary for beginners, a text for the school of the grammaticus. The source for the Danieline additamenta is a more advanced commentary on Vergil, for more experienced readers" (Stocker 1963, 14).

${ }^{9}$ Cf. Fowler 1997, 73-74.

10 For general treatments of ancient superstitions see, for example, Riess 1893 (cf. Riess 1895), Calderone 1972; neither is the belief in the unreliability of autumn dreams mentioned in general studies on dreams in antiquity, such as Kessels 1978, Hanson 1980 or Harrison 2013. 


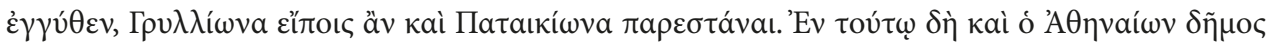



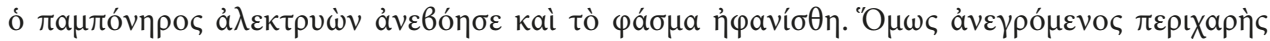

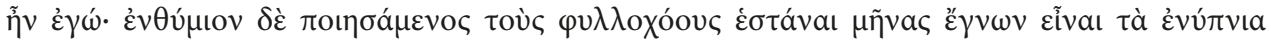
$\psi \varepsilon v \delta \varepsilon ́ \sigma \tau a \tau a$ (Alciphr. Ep. 2, 2).

"May he be damned and perish badly that vilest, dirtiest cock that woke me by his cry while I was dreaming a pleasant dream. For I dreamt, my dearest neighbour, that I was someone illustrious and mightily rich, and that an array of servants followed me around who, as I thought, were my stewards and accountants. And I saw that both my hands were covered in rings and bore gems worth many talents: and my fingers were soft and had no memory of the mattock. Flatterers also appeared nearby - you would have said that I was attended by Gryllion and Pataecion. And then of course all the people of Athens gathered in the theatre and were shouting that I should be elected general. And in the midst of voting, that rascal of a cock crowed and the vision vanished. Still, on awaking, I was mighty glad; but then, remembering that it was fall, I realized that the dream was absolutely false".

Iophon's first feeling on awaking is joy, because his dream might turn out to be prophetic, but the thought of the autumn quickly crushes his hopes: thanks to the cock, he can no longer enjoy the dream, and because of the season neither can he hope for it to come true. The reference to the superstition is well suited to the general style of the letter that characterises Iophon as a simple uneducated farmer, such as his use of superlatives

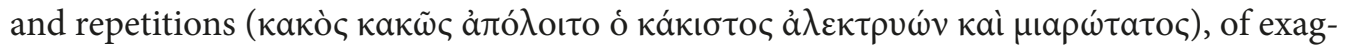

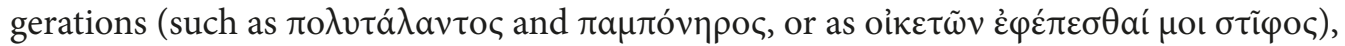

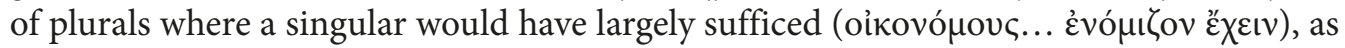

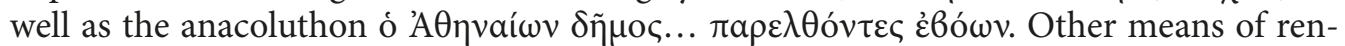
dering Iophon's character are the naïveté of the details mentioned (the costliest rings worn on every finger, attention from professional flatterers, ${ }^{11}$ the unanimous vote of the Athenians electing him $\sigma \tau \rho \alpha \tau \eta \gamma o ́()$ ) and the gradual transition from wealth to admiration as the narrator's fancy takes flight, rendering his dream more and more fantastic. ${ }^{12}$ In this context, Alciphron ends his letter on a humorous note, adroitly bringing up the belief in the fallaciousness of autumn dreams and stressing the contrast between Iophon's dream and the waking reality.

Another example that shows how current the superstition was in late antiquity, appears in a Christian context, in one of the letters in which St. Basil defends himself before the clergy of Neocaesarea against criticism concerning his establishment of ascetic communities and the introduction of a new type of psalmody. His opponents (in particular, bishop Atarbios who is not named in this letter, but is clearly hinted at) went so far as to use a revelation seen in a dream to denounce Basil's teaching; Basil discards the vision, reducing it to the rank of "autumn dreams":

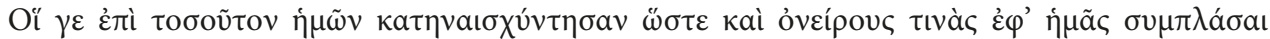



11 On Gryllion and Pataecion, see Costa 2001, 133.

12 In depicting his rustic letter-writers, Alciphron greatly relied on comedy (cf. Benner, Fobes 1949, 5-17; Konstantakos 2005, 18). It would be tempting to imagine that Alciphron's use of the superstition to characterize Iophon might go back to a model in the New Comedy, but this is impossible to prove: one probable model for Iophon's letter (with striking resemblance to the opening imprecations against the cock) has been discovered by Reich in Lucian's Gallus (cf., in particular, sect. 1 and 12) and used as an argument for the relative dating of the two authors; Lucian, however, does not mention the unreliability of autumn dreams. 


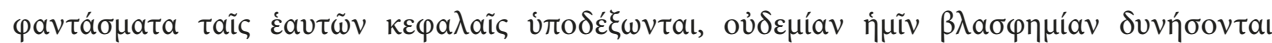

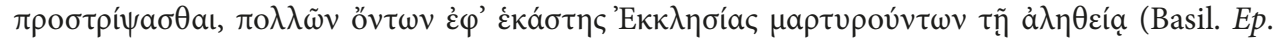
207, 1).

"They have indeed gone to such lengths of shamelessness as to even invent some dreams, slandering our teaching as harmful. These people, were they to receive within their heads all the visions of autumn months, will not be able to attribute to us any blasphemy, as there are many witnesses to the truth in every church".

With remarkable casualness Basil refers to dreams seen in the autumn months as

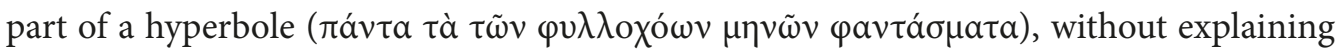
the allusion in any way. ${ }^{13}$ Comparison with other letters on the same subject (especially Ep. 204 and Ep. 210) shows that for Basil the expression was largely analogous to a much commoner idea of unreliability of dreams seen after drinking, the kind of behaviour for which he criticized Atarbios and other followers of Sabellianism:

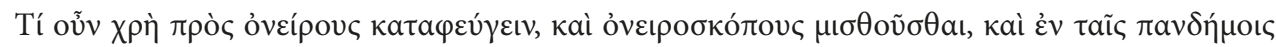



"Why then do you need to resort to dreams and to hiring dream-tellers, why make us the subject of banter over drink at your public banquets?"14

The fact that Basil expected his addressees among the Neocaesarean clergy to understand his very brief reference to autumn dreams suggests that the belief was still current among commoners. Basil uses the reference to the ancient superstition to brand his theological opponents as being no different from pagans and to emphasize the difference between his own enlightened version of faith and Atarbios' unwholesome influence on his simple-minded followers. ${ }^{15}$

Both Alciphron's and Basil's evocation of the unreliability of dreams in autumn months show that the belief was associated with common, unsophisticated way of thinking, and it is not surprising that the references to the belief are scanty in ancient literature. Fortunately for us, the superstition gained attention from philosophers, and Plutarch even preserves a debate concerning the causes behind the belief in one of his dialogues in the Quaestiones


$10,734 \mathrm{~d}-736 \mathrm{~b})$. Plutarch begins the dialogue by setting the circumstances in which the participants came to discuss this topic: young Florus, excited with reading by Aristotle's Physical problems that he has only lately discovered, uses every possibility to discuss the

13 The allusion is in fact so fleeting that it seems to have passed unobserved by Deferrari 1986, $182-$ 183 who makes no comment on the expression.

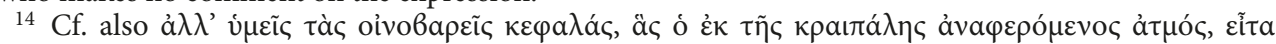

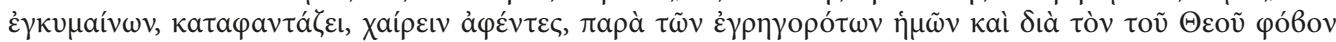


wine that are revealed by the vapor, rising and swelling from their drinking-bouts, and hear from us, who have awakened and cannot keep quiet for the fear of God, of the harm that has been done to you" (Basil. Ep. 210,3). The way in which Basil adroitly combines the idea of unreliability of dreams seen after drinking with the criticism of the mours of Atarbios' circle, is well analysed by Pouchet 1992, 482; cf. in particular, «L'impression se mue en certitude lorsque Basile $\langle\ldots\rangle$ met en connexion songes et ébriété avec les banquets

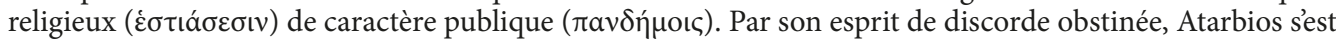
dérobée à l'Esprit-Saint et voici qu'à son insu, il est à la merci d'un esprit menteur, 'celui qui opère maintenant dans les fils de la désobéissance'» (ibid.; the last reference is to Basil. Ep. 210, 10).

${ }^{15}$ Cf. Pouchet 1992, 481. 
problems raised by Aristotle, and among them the alleged unreliability of autumn dreams: although the question is not examined in the surviving text of the treatise, it must have been present in the variant of Physical problems known to Florus and Plutarch. ${ }^{16}$ In the beginning of the dialogue Plutarch's sons are ready to accept, without probing further, Aristotle's explanation that blamed unreliable autumn visions on the quality of autumn food, in particular, fruit (734 e-f $=$ Aristot. fr. 735 Gigon). An alternative explanation is presented by Favorinus who, despite being a devout peripatetic ${ }^{17}$, in this case evokes Democritus' atomistic theory of images, connecting the unreliability of dreams with the harshness of autumn air and the winds that distort the images, slowing their progress, or even leading them off their course $(735 \mathrm{a}=$ Democr. A $77 \mathrm{DK}) .{ }^{18}$ The third and final explanation is offered by Autobulus, one of Plutarch's sons, who jokingly accuses Favorinus of citing Democritus only to win favor for Aristotle's view on the subject; his own explanation, despite being characterized as Aristotelian in its origin, differs from the physiologi$\mathrm{cal}$ and dietetic explanation that was offered at first. Taking as his starting point the term $\varphi v \lambda \lambda$ oxóos that designates the season when dreams are untrustworthy, and pointing out that the fall of leaves is caused by the predominance of dryness and the cold over the humidity and warmth in late autumn, Autobulus connects the unreliability of dreams with these same qualities that are proper to the autumn air and that affect the humans' health in general and their breath in particular, thereby injuring the soul's capacity for divination. ${ }^{19}$

Plutarch does not explicitly favour one of the three explanations, although Aristotle's dietetic theory seems to be presented as reductive, and Democritus' atomistic approach is declared (albeit with irony) weaker than Aristotle's interpretation (735c), so that Autobulus' interpretation (as the last voiced and left uncontradicted) appears to have an advantage over the others. The comparison of two distinct philosophical paradigms (peripatetic and atomistic) is, of course, central for the development of the dialogue. It is, however, easy to forget that behind these heterogenous philosophical approaches the problem in question is a popular superstition that saw an analogy between the fall of leaves and dreams, brief and unreliable. ${ }^{20}$ Philosophy only tried to give a reasonable explanation to this belief. Plutarch's dialogue shows that it was certainly current in the classical age, so much so that it even received a philosophical interpretation from Democritus and Aristotle; given the

16 Cf. Braccini 2014, 301; for a general discussion of the text of the Physical Problems known to Plutarch, see Sandbach 1982, 223-225, with literature.

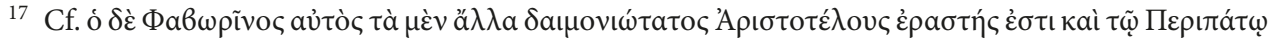


stotle and attributes greatest credibility to the peripatetic teaching." (Plut. Quaest. conv. 8, 10, 734f).

18 More generally on Plutarch's reception of Democritus' theory of eidola, see Herschbell 1982, 103105. Favorinus' speech in the dialogue (Quaest. conv. 8, 10, 734f-735c) is one of the main sources on Democritus' theory of dreams: see also Salem 1996, 211-213; Cambiano 1980, esp. 439-441; Brillante 1986, $30-31$.

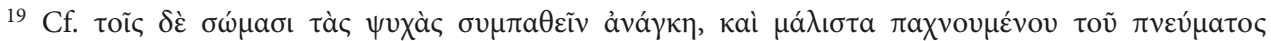


fluenced as well as the bodies, and with the great condensation of the spirit the capacity for divination is dimmed, as a mirror filled with mist (i.e. breathed upon)" (Quaest. conv. 8, 10, $736 \mathrm{a}-\mathrm{b}$ ). For the analysis of Aristobulus' opinion and of the way it is presented in the dialogue, see Braccini 2014, 55-57.

20 As is often the case with popular beliefs, the exact idea behind this analogy is difficult to grasp. Leaves, however, are regularly evoked as a paradigm of ephemerality (as in the standard comparison between the frailty of man's life or the succession of human generations and the 'generation of leaves'; cf. Hom. Il. 6, 146-149; 21, 464-466; Mimn. fr. 2, 1-4 West; Aristoph. Av. 685; Hor. Ars 60-62), and as such constitute an obvious counterpart to the fickleness and unreliability of dreams. 
stability and longevity of superstitions, one is justified in assuming that before coming to the attention of philosophers, the belief had been current for a considerable while, even though it does not seem to have been evoked in the extant texts from the archaic and classical periods. This should not surprise us, however, as the unreliability of autumn dreams is at once very specific as regards the circumstances (the season in which the vision is seen) and connotated as a belief held by simple, uneducated people that were not often represented in works of literature. It should finally be noted that the belief seems to have been current only in the Greek tradition: the term $\varphi v \lambda \lambda$ oxóoৎ which is central to it does not have a Latin equivalent (so that Servius is obliged to paraphrase it quo tempore folia cadunt), and the superstition does not seem to have been invoked in Roman literature. It could, however, be included in Roman treatises on dreams that borrowed freely from Greek oneiromancy; one of these Servius had apparently used.

\section{Servius' argumentation}

We can turn now to the reasons behind Servius' evocation of the superstition in his commentary on Aen. 6, 282-284. As has been noted above, Servius as a commentator tends to focus on information either necessary for pedagogical reasons (explanation of Vergil's text in a classroom), or one that was authoritative to an extent that it could not be ignored. Although the scholium on v. 284 mentions no names, Servius' wording (in particular, the expression qui de somniis scripserunt) makes it clear that his information comes from some kind of treatise on the subject of dreams. The same oblique reference appears once again in Aeneis 6, in the scholium on v. 893, providing a helpful clue to the approach of Servius' source to Vergil's text.

At the end of Aeneis 6, as Aeneas and Sibyl prepare to leave the Underworld, they are guided by the shade of Anchises to the twin gates of Sleep. Vergil took this image over from Homer $(\mathrm{Od} .19,562-567)$, where it is evoked by Penelope in order to demonstrate how difficult it is to distinguish between prophetic and false dreams. Vergil preserves the respective allegorical meaning of the two gates, but combines it with the idea of the Underworld (a connection that was not present in Homer), and unexpectedly makes Aeneas exit through the ivory gate reserved for false dreams:

Sunt geminae Somni portae, quarum altera fertur

cornea, qua veris facilis datur exitus umbris,

altera candenti perfecta nitens elephanto,

sed falsa ad caelum mittunt insomnia Manes.

his ibi tum natum Anchises unaque Sibyllam

prosequitur dictis portaque emittit eburna (Verg. Aen. 6, 893-898).

"There exist twin gates of Sleep, one of which, as they say, is of horn and through it an easy outlet is given to the real shades; the other is perfect gleaming with splendid ivory, but the Manes use it to send false visions skywards. It is there then that Anchises, with these words, attended his son and Sibylla and let them out through the ivory gate."

This passage is one of the most debated in the whole of Vergil's auvre. Multiple explanations have been proposed by modern research none of which is wholly satisfactory:

(a) the ivory gate is located in the vestibulum Orci, and the expression insomnia falsa (v. 283-284) that echoes somnia vana of v. 896 allows the reader to identify the 
two places, suggesting that Aeneas was obliged to take the same gate that he had used to gain entry to the Underworld; ${ }^{21}$

(b) Aeneas is in fact not a shade at all, and consequently cannot go out of the gate reserved for real dreams; ${ }^{22}$ in a similar line of thinking, Aeneas no longer has the Golden Bough and thus has to blend in with the false shades in order to leave the Hades; ${ }^{23}$

(c) the choice of gate alludes to the time of Aeneas' departure from the Underworld. According to another ancient superstition, only dreams seen after midnight were trustworthy; Aeneas' exit through the ivory gates would point to his return before midnight; 24

(d) for Vergil, the detail was means of dissociating the prophecies heard in the Underworld and the actual future of the Rome: although Vergil's readers will recognize actual events of Roman history in the prophecies, the poet uses this detail in order to preserve the intrigue and to render the accomplishment of his task less certain from Aeneas' point of view. Thus, his experience is presented as imprecise and somewhat deceptive, suggesting also that Aeneas will no longer remember it on his return to the realm of the living; ${ }^{25}$ from a similar perspective, Aeneas' exit through the gate of ivory has been viewed as enhancing the dreamlike atmosphere of Aeneis $6 .^{26}$

If modern scholarship is at loss as to how Vergil's meaning should be interpreted, the ancient readers also struggled to agree on a single approach, as Servius' entry on the passage makes it clear. Servius regroups the proffered explanations, starting with the "poetic" interpretation that Vergil sought to present Aeneas' experience as unreal (et poetice apertus est sensus: vult autem intellegi falsa esse omnia quae dixit, "and from the

${ }^{21}$ Highbarger 1940, 71; Steiner 1952, 94-95.

22 Thus, already Heyne 1832, 1043: "Educendus erat Aeneas ex locis inferis per aliam portam, quam qua subierat. Incidit poeta in portas Somni. Iam eae duplices sunt, altera, per quam veris umbris datur; per hanc Aeneas et Sibylla, quae non erant verae umbrae, emitti nequibant; restabat itaque, ut per alteram portam dimitterentur"; cf. also Paratore 1954, 353 ("egli non deve presentarsi in sogno a nessuno; può uscire quindi dalla porta delle visioni inani”); Reed 1973, 314-315; Cockburn 1992, 363-364.

23 Thus, Rolland 1957, 186; Kopff, Marinatos Kopff 1976, 249-250.

24 The connection was first proposed by Everett 1900 who emphasized occasional references to the progression of time in the Aeneis 6; the interpretation was embraced by Norden 1903, 339-340, but did not gain favor with later scholars: see in particular, Clausen 1964, 147 who refuses to reduce this suggestive detail to a mere indication of time, as well as Steiner 1952, 94; Otis 1959, 174; cf. Harrison 2013, 179-181.

25 Brignoli 1954; Tarrant 1982, 53-55; Gotoff 1985; Molyviati-Topsis 1995, esp. 641-643 and 650; von Möllendorff 2000, esp. 63-65.

26 Thus, Otis 1959, 176-179 (cf. also Steiner 1952, 96). In order to justify Aeneas' leaving through the door reserved for false dreams, in spite of the connection between prophecies that Aeneas hears in the Hades and the future of Rome that would have been evident for Vergil's readers, Otis adds a psychological dimension to this interpretation: cf. "most fundamentally then, the identification of Aeneas' vision as a dream signifies that the primary struggle and action of the poem (or more exactly of the Odyssean Aeneid, Books 1-6) is within Aeneas' own consciousness, not outside it" (Otis 1959, 179); a similar emphasis on the subjectivity of Aeneas' experience in the Hades is found in Setaioli 2010, esp. 33-34. For other, less influential and largely unconvincing interpretations of Aeneas' departure through the Gate of Ivory, see Mellinghoff-Bourgerie 1990, 216-221 and independently Kilpatrick 1995, 64-66 who compare ivory and horn from the point of view of their respective transparency/opacity; Michels 1944, 147-148 and Frantantuono 2007, 635 who argue for a reference to Lucretius and to the Epicurean rejection of afterlife; Maleuvre 1996, 93-95 who sees in Vergil's use of this detail an implicit criticism of his hero. The most radical solution is, of course, to modify the transmitted text: thus, Nauck 1874, 89-99, and recently Kraggerud 2002, 134-135 and 140-142 (see also Cockburn 1992, 363 and 364). 
poetic point of view, the meaning is clear: he implies that everything he said was false"). He then passes on to the "physiological" explanation according to which the gate of horn is seen as a reference to visual perception (suggesting that the phenomenon perceived is real), while the gate of ivory refers to the mouth (implying that the phenomenon only talked of, but not seen, may be false). The third interpretation is attributed to certain "authors who wrote on dreams":

Est et alter sensus: Somnum novimus cum cornu pingi. Et qui de somniis scripserunt dicunt ea quae secundum fortunam et personae possibilitatem videntur habere effectum. Et haec vicina sunt cornu: unde cornea vera fingitur porta. Ea vero quae supra fortunam sunt et habent nimium ornatum vanamque iactantiam dicunt falsa esse; unde eburnea quasi ornatior porta fingitur (Serv. ad Aen. 6, 893).

"There is also another meaning: we know that the Dream is depicted with a horn. And those who have written on dreams say that those visions that correspond to a person's destiny and capacity can be realized. And these resemble the horn: hence, the gate of horn is imagined as the gate of real dreams. But they say that those visions that exceed one's destiny and are excessively ornate or vainly ostentatious are false; hence, that gate is imagined as the gate of ivory, as being too adorned"

The reference qui de somniis scripserunt in this passage is strictly identical with the reference that Servius had used in his note on v. 284, a coincidence in wording that suggests that in both cases Servius was evoking the same scholarly source. ${ }^{27}$ This must have been a treatise that dealt in some form or other with the possible solutions for the problem of Aeneas' exiting through the gate of false dreams in order to return to the world of the living: despite Servius' imprecise reference (qui de somnibus scripserunt) and the conciseness of his summaries of the arguments, we can assume that the treatise dealt with the distinction of prophetic and false dreams with special attention to the treatment of dreams in literature. It is unlikely that the whole treatise was dedicated solely to Aeneas' return by the ivory gate, but the discussion of this problem would have occupied a prominent place. A comparison of the two scholia shows that with regard to vv. 893-898 the treatise provided an allegorical interpretation of the choice of horn and ivory as the materials for the two gates. The fact that it examined both Aeneas' descent and his return also implies that the treatise identified the porta eburna and the vestibulum Orci: the scholar that Servius used would have tried to extract as much arguments as possible from Vergil's text emphasizing, in particular, the resemblance of the expressions somnia vana nesting on the Elm (v. 283-284) and the insomnia falsa that the Manes send forth through the gate of ivory (v. 896). An argumentation of this kind would justify the attempt to find a reference to the popular superstition concerning autumn dreams in the description of the Elm in the vestibulum Orci: if used as a supplementary piece of evidence, the idea would not look completely out of place, despite the fact that Vergil's text (Aen. 6, 282-284) suggests no connection with the fall, and the epic comparison of the shades in the Underworld with autumn leaves at Aen. 6, 309-310 might have also been used to further strengthen the association.

Servius' evocation of autumn dreams in his commentary to Aen. 6, 284, although not strictly necessary for the understanding of Vergil's text, constitutes a trace of a fairly

27 E. Jeunet-Mancy seems to accept this identification, as suggested by the cross-reference (cf. JeunetMancy 2012, $201 \mathrm{n} .871$ ). The use of plural is regular in unprecise references of this kind and need not imply multiple sources. 
elaborated exegetical tradition on Aen. 6, 282-284 and 893-898. His scholium on v. 893 balances the oneiric explanation against a physiological one, probably stemming from a different source. But what was his own approach, and why did he choose, contrary to his usual practice, to evoke an opinion that was not easily deduced from Vergil's text and abstruse? Although Servius visibly used the reference qui de somniis scripserunt to distance himself somewhat from the main approach and the conclusions of the treatise on dreams, it seems that he did accept several of the premises. His wording in the commentary on v. 284 (quod per transitum tetigit) suggests that he at least accepted the possibility that Vergil might have been alluding to the superstition on the unreliability of autumn dreams by placing the vana Somnia on the Elm. There is also little doubt that he agreed with the identification of the porta eburna with the vestibulum Orci, ${ }^{28}$ and deduced from it that Vergil must have been emphasizing the unreliability of Aeneas' experience in the Underworld, as his comment on the beginning of Aeneas' descent suggests:

IN MEDIO: aut vestibulo; aut absolutum est, et intellegimus hanc esse eburneam portam per quam exiturus est. Quae res haec omnia indicat esse simulata, si et ingressus et exitus simulatus est et falsus (Serv. ad Aen. 6, 282).

"In the middle: either in the middle of the vestibulum; or to be taken absolutely, and we then understand that this is the gate of ivory though which he (Aeneas) will leave. Which shows that all this (i.e. Aeneas' descent into the Underworld) is imaginary, if both the entry and the exit are imaginary and unreal."

The last remark will be echoed in Servius' commentary on the exit scene (cf. vult autem intellegi falsa esse omnia quae dixit "he implies that everything he said was false", Serv. ad Aen. 6, 893), allowing us to reconstruct a deliberate attempt to present a logical, uncontradictory picture of Aeneas' descent and return from the Hades. It is however also clear that Servius placed particular emphasis on Homer's influence, much more than his source would have had. Thus, the grammarian specifically stated that the Vergil's description of the gates of sleep was taken over from Homer (est autem in hoc loco Homerum secutus "he followed Homer in this passage", Serv. ad Aen. 6, 893), and in his note on v. 284 an actual quotation from Homer is used in support of his interpretation of the epithet vana and the idea that the prophetic dreams must come from above:

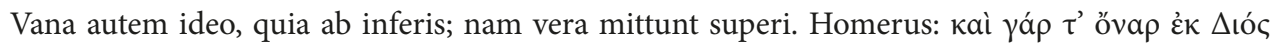
غ̇otív (Serv. ad Aen. 6, 284).

Given the continuity of Servius' comments on Aen. 6, 282-284 and 893, it is possible to conclude that his approach to Vergil's depiction of Aeneas' descent and return was based on two ideas: namely, that the porta eburna had to be identified with the vestibulum Orci and that the dreams sent from the Underworld were unreliable by definition, whereas the prophetic dreams were sent by Zeus. If one admits that the two ideas were part of a single interpretation, it follows that Servius would have located the door made of horn at the point where the prophetic dreams leave the heavens to appear to the dreamer, just as the false dreams leave the Hades through the gate of ivory. The geminae portae would then be imagined as identical, but placed on the opposite sides of the universe, rather than side by side. This would also explain why Servius, who is generally rational and not given

${ }^{28}$ Cf. Austin 1977, 121 (ad Aen. 6, 284). 
to mysticism, insisted on the deceptiveness of Aeneas' experience in the Underworld (ad v. 282 and v. 893): this exegetical approach presupposes that Aeneas had no other option than to exit the Hades through the eburna porta, and everything he learned there would have automatically become vana somnia. ${ }^{29}$

\section{References}

Austin R. G. (ed., comm.). P. Vergili Maronis Aeneidos Liber Sextus. Oxford, Clarendon Press, 1977.

Benner A. R., Fobes F.H. (eds.). The Letters of Alciphron, Aelian and Philostratus. Cambridge Ma., Harvard UP, London, W. Heinemann, 1949.

Braccini T. (ed., comm.), Pellizer E. (trad.) Plutarco, Conversazioni a tavola, libro ottavo. Napoli, M. D’Auria, 2014.

Brignoli F. M. La porta d’avorio del libro VI dell'Eneide. GIF 1954, 7, 61-67.

Brilliante C. Il sogno nella riflessione dei presocratici. MD 1986, 16, 9-53.

Calderone S. Superstitio, in: H. Temporini (ed.), Aufstieg und Niedergang der römischen Welt, 1.2, Berlin, New York, W. de Gruyter, 1972, 377-396.

Cambiano G. Democrito e i sogni. Siculorum gymnasium 1980, 33 (1), 437-450.

Clausen W. An Interpretation of the Aeneid. HSCP 1964, 68, 139-147.

Cockburn G. T. Aeneas and the Gates of Sleep: An Etymological Approach. Phoenix 1992, 46, 362-364.

Conington J. (ed., comm.). P. Vergili Maronis Opera. The Works of Vergil with a Commentary, Vol. II. London, Whittaker \& Co., 1863.

Costa C. D. N. (ed., comm.). Greek Fictional Letters: A Selection with Introduction, Translation and Commentary. Oxford, Oxford UP, 2001.

Dain Ph. (ed.), Kerlouégan F. (rev.) Mythographe du Vatican III, traduction et commentaire. Besançon, Presses universitaires de Franche-Comté, 2005.

Deferrari R. J. (ed.). Saint Basil, The Letters. Vol. III. London, W. Heinemann, New York, G. P. Putnam's Sons, 1986.

Fowler D. The Virgil Commentary of Servius, in: C. Martindale (ed.), The Cambridge Companion to Virgil. Cambridge, Cambridge UP, 1997, 73-78.

Frantatuono L. A Brief Reflection on the Gates of Sleep. Latomus 2007, 66 (3), 628-635.

Frazier F. Sirinelli J. (ed., trad.). Plutarque, CEuvres morales. Tome IX. 3 : Propos de table, livres VII-IX. Paris, Les belles lettres, 1966.

Gotoff H. C. The Difficulty of the Ascent from Avernus. CPh 1985, 80, 35-40.

Hanson J. S. Dreams and Visions in Graeco-Roman World and Early Christianity, in: W. Haase (ed.), Aufstieg und Niedergang der römischen Welt, 2, 23, 2, Berlin, New York, W. de Gruyter, 1980, 1395-1427.

Harrison J. Dreams and Dreaming in the Roman Empire: Cultural Memory and Imagination. London, New York, New Dehli, Sydney, Bloomsbury, 2013.

Hershbell J.P. Plutarch and Democritus. QUCC 1982, 10, 81-111.

Heyne Chr. G. (ed., comm.). Publius Virgilius Maro, varietate lectionis et perpetua adnotatione illustratus / curavit G. P. E. Wagner. Vol. II. ${ }^{4}$ Leipzig, Hahn, London, Black, Young \& Young, 1832.

Highbarger E. L. The Gates of Sleep: an Archeological Examination of Vergil, Aeneid VI, 893-898. Baltimore, John Hopkins Press, 1940.

Huby P. M. The Paranormal in the Works of Aristotle and his Circle. Apeiron 1979, 13, 53-62.

Jeunet-Mancy E. (ed., comm.). Servius. Commentaire sur l'Énéide de Virgile, livre VI. Paris, Les belles lettres, 2012.

Kaster R. A. Guardians of Language: The Grammarian and Society in Late Antiquity. Berkeley, Los Angeles, Oxford, University of California Press, 1997.

Kessels A.H.M. Studies on the dream in Greek literature. Utrecht, HES, 1978.

Kilpatrick R. S. The Stuff of Doors and Dreams (Vergil, Aeneid 6.893-98). Vergilius 1995, 41, 63-70.

Konstantakos I. M. Aspects of the Figure of the ä $\gamma \rho$ otкo in Ancient Comedy. RhM 2005, 148, 1-26.

${ }^{29}$ An earlier version of this paper was read at the $46^{\text {th }}$ International Philological Research Conference hosted by S.-Petersburg State University in March 2017. I am very grateful to all participants of the discussion (and particularly to Prof. A. K. Gavrilov and to D. V. Keyer) for their comments and helpful criticism. M. M. Pozdnev, S. K. Egorova and two anonymous reviewers read and commented on the article: their keen remarks have helped me to improve the argumentation. 
Kopff E. C. Marinatos Kopff N. Aeneas: False Dream or Messenger of the Manes (Aeneid 6.893ff.). Philologus 1976, 120 (2), 246-250.

Kraggerud E. What is Wrong with the Somni Portae? (Aen. 6, 893-898). Symbolae Osloenses 2002, 77, $128-$ 144.

Maleuvre J.-Y. Porte d'ivoire et rameau d'or : éléments de cacozélie dans le sixième livre de l'Énéide. RÉA 1996, 98, 91-107.

Mellinghoff-Bourgerie V. Les incertitudes de Virgile : contributions épicuriennes à la théologie de l'Énéide. Bruxelles, Latomus, 1990.

Michels A. K. Lucretius and the Sixth Book of the Aeneid. AJPh 1944, 65, 135-148.

von Möllendorff P. Aeneas und Odysseus. Die ,Tore des Schlafs' in Aen. 6, 893-899, in: J.P. Schwindt (ed.), Zwischen Tradition und Innovation. Poetische Verfahren im Spannungsfeld klassischer und neuerer Literatur und Literaturwissenschaft. München, Leipzig, 2000, 43-66.

Molyviati-Topsis U. Sed falsa ad caelum mittunt insomnia Manes (Aeneid 6.896). AJPh 1995, 116, 639-652.

Nauck A. Kritische Bemerkungen V, in: Mélanges gréco-romains tirés du Bulletin de l'Académie Impériale de Saint-Pétersbourg III (1869-1974). St.-Pétersbourg, 1874, 9-102.

Norden E. (ed., comm.). P. Vergilius Maro, Aeneis Buch VI. Leipzig, B. G. Teubner, 1903.

Otis B. Three Problems of Aeneid VI. TAPhA 1959, 90, 165-179.

Paratore E. Virgilio. Firenze, G. C. Sansoni, 1954.

Pouchet R. Basile le Grand et son univers d'amis d’après sa correspondance : une stratégie de communion. Rome, Institutum patristicum Augustinianum, 1992.

Reed N. The Gates of Sleep in Aeneid 6. CQ 1973, 23, 311-315.

Riess E. Aberglaube. RE I. 1, 1893, 29-93.

Riess E. Ancient Superstition. TAPhA 1895, 26, 40-55.

Rolland L.-F. Pourquoi Énée sort-il des Enfers par la Porte d'Ivoire, la Porte des Songes Faux (Énéide, VI, 898)?. CRAI 1957, 101 (2), 185-188.

Salem J. Démocrite : grains de poussière dans un rayon de soleil. Paris, VRIN, 1996.

Sandbach F. H. Plutarch and Aristotle. ICS 1982, 7, 207-232.

Setaioli A. Le porte del sonno nel VI libro dell'Eneide. Aevum Antiquum 2010, 10, 13-38.

Steiner H. R. Der Traum in der Aeneis. Bern, Stuttgart, Paul Haupt, 1952.

Stocker A. F. Servius Servus Magistrorum. Vergilius 1963, 9, 9-15.

Tabárez A. El olmo de los sueños (Aen.6.282-284). Cuadernos de Filología Clásica. Estudios Latinos 2010, 30 (1), 27-49.

Tarrant R. J. Aeneas and the Gates of Sleep. CPh 1982, 77, 51-55.

For citation: Kazanskaya M.N. Autumn Dreams: Servius on Aen. 6, 282-284. Philologia Classica 2017, 12(2), 142-153. https://doi.org/10.21638/11701/spbu20.2017.204

\section{ОСЕННИЕ СНЫ: КОММЕНТАРИЙ СЕРВИЯ К АЕN. 6, 282-284}

\section{Мария Николаевна Казанская}

Институт лингвистических исследований РАН,

Российская Федерация, 199004, Санкт-Петербург, Тучков пер., 9; subura@mail.ru

Санкт-Петербургский государственный университет, Российская Федерация,

199034, Санкт-Петербург, Университетская наб., 7-9; m.kazanskaya@spbu.ru

Статья посвящена античному суеверию, упомянутому в комментарии Сервия (Serv. ad Aen. 6, 284): Сервий сообщает, ссылаясь на авторов, писавших о снах, что поздней осенью сновидения особенно ненадежны. В первой части статьи представляется обзор других упоминаний об этом народном поверье (Plut. Quaest. conv. 8, 10, 734d-736b; Alciphr. Ep. 2, 2; Basil. Ep. 207, 1); во второй предпринимается попытка реконструировать аргументацию источника, на который опирался Сервий (qui de somniis scripserunt), а также определить подход самого грамматика к данному пассажу. Показывается, что замечание о ненадежности осенних снов, пусть и не представляет ценности с точки зрения понимания вергилиевского текста, восходит к более широкой экзегетической традиции, которая, в частности, усматривала связь между Aen. 6, 282-284 и 6, 893-898.

Ключевые слова: Вергилий, Сервий, ворота снов, античные суеверия, Плутарх, Алкифрон, Василий Великий, Аристотель о снах, Демокрит о снах. 